\title{
Otters in Greece
}

\author{
S.M. Macdonald \\ and \\ C.F. Mason
}

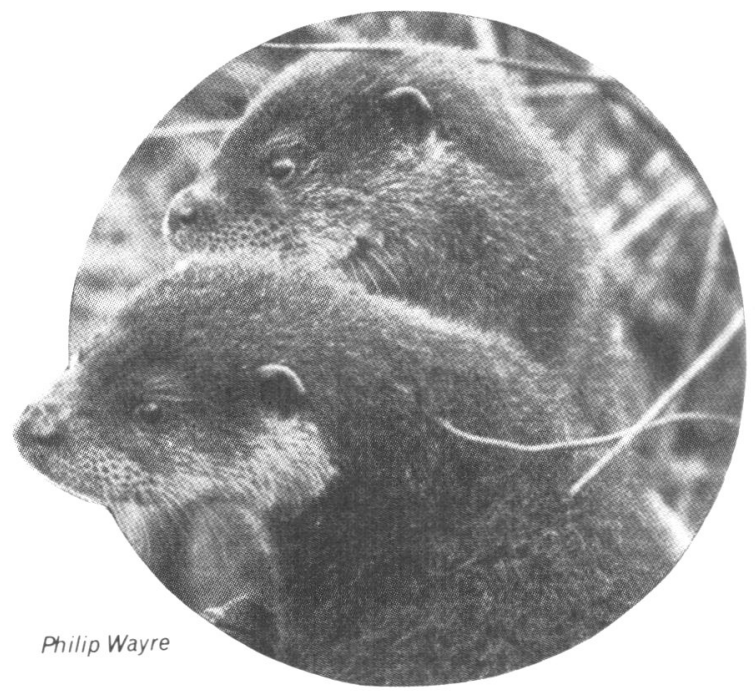

Nearly two-thirds of 200 sites the authors visited for an otter survey of mainland Greece early in 1981 showed evidence of otters. In some places there were signs that populations were becoming fragmented, but in some of the intensively farmed areas they were widespread in the irrigation ditches, where reeds and bramble thickets gave them cover. The study was financed by the Vincent Wildlife Trust.

Recent reports have suggested that otters Lutra lutra are now rare in much of their north European range. ${ }^{2}{ }^{4}$ The species has also been listed as one of the threatened mammals of the Mediterranean region, ${ }^{5}$ although there has been little or no recent information on its status in many of these countries. A field survey of otters was therefore undertaken in Greece.

\section{The Study Area}

The area surveyed may be considered as three major regions: the Peloponnese, the east-central mainland extending from Athens to the Albanian/Jugoslav border across to Thessaloniki, and north-east Greece east of Thessaloniki. The western edge was the Pindos Mountains; the borders with Yugoslavia and Bulgaria were also mountainous.

The large irrigated plains of central and northern Greece are mainly arable, growing cereals, sugar beet and cotton. Irrigation schemes compensate to some extent for the dry summers, and the irrigation ditches together with the river embankments have produced a landscape similar to the English fens. Deforestation is extensive and affects the flow of many rivers. Agriculture accounts for 20 per cent of the gross national product, but more land will have to be irrigated if productivity is to increase.$^{3}$ Many rivers were found to be organically polluted, but few were visibly polluted by industrial waste. Some pollution was caused by mining and stone workings, and many river beds are used for gravel extraction.

Methods

The survey, which was carried out between 27 March and 14 April 1981, 


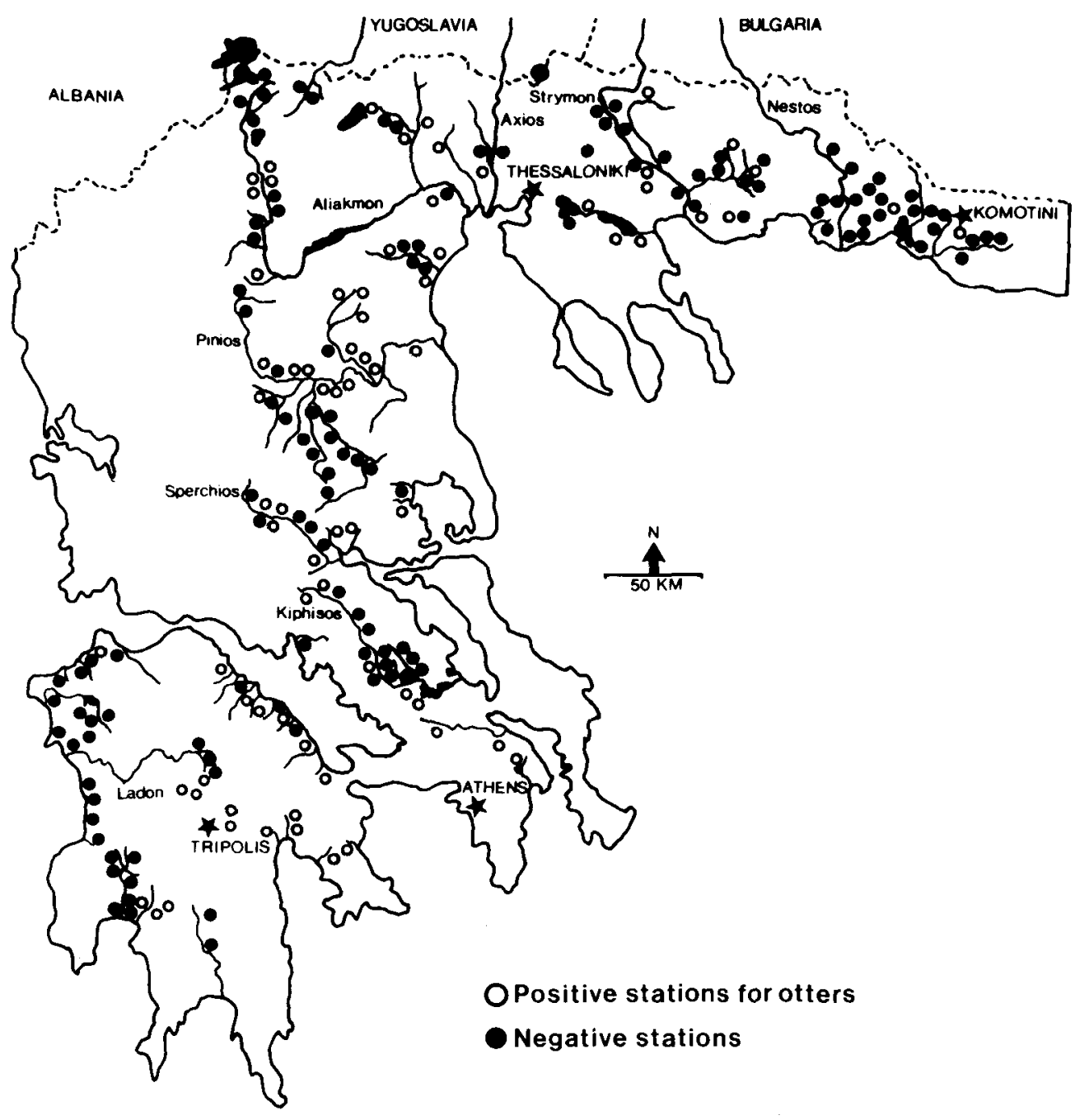

included rivers, drainage ditches, lakes and marshes. Stations visited included bridges or places where a river ran close to a road, and at each station a minimum distance of $200 \mathrm{~m}$. was searched for otter signs - faeces (spraints) and footprints. Otters were presumed absent when, after a search of $600 \mathrm{~m}$. of river or $1 \mathrm{~km}$ of marshland, no signs had been found. Notes were made on the habitat at each station. Spraints were collected from stations throughout the region and these were washed through a fine sieve for examination.

\section{Distribution of Signs}

Of the 200 stations visited, 124 showed signs of otters (62 per cent) - see fig. 1 . Many other rivers and lakes shown on recent maps were found to be dry or drained.

In the Peloponnese 29 of 50 stations ( 58 per cent) produced signs of otters. Of 16 stations north or east of Tripolis only 3 (18.8 per cent) proved positive, and it seemed that the west of the Peloponnese (with 76.5 per cent positive 
stations) held the greater part of the local otter population. In east-central Greece signs were found at 54 of the 97 stations visited (55.7 per cent) but distribution was not uniform. In the plain of the River Kiphisos around Levadia 77 per cent of 13 stations proved positive while further north, in the lowlands of the Pinios river catchment, 55 per cent of 20 stations produced signs. Evidence was found at 5 of 11 stations ( 45.5 per cent) in the Sperchios valley, and at 58.3 per cent of 12 stations in the Aliakmon river catchment. In the lowlands immediately west of Thessaloniki signs were found at only 3 of 8 stations visited (37.4 per cent). In the north-east (east of Thessaloniki) 41 of 53 stations surveyed ( 77.3 per cent) were positive. Twenty of these were in the catchment of the Strymon river and signs were found at 70 per cent. A further 22 stations occurred in the Nestos river delta and in the lowlands south of Komotini; 91 per cent of these were positive.

Throughout the area no relationship was found between the width of rivers or streams and the presence of otters. Stations on rivers or streams could, however, be classified into three categories; upland, lowland and drainage ditches. Upland rivers and streams were not associated with agricultural plains and were swiftly flowing, with riffles over stony substrata; of 80 such stations visited 42 ( 52.5 per cent) proved positive. Lowland rivers and streams in the fertile plains had many pools and/or gravel banks; of 84 such stations signs were found at 50 ( 59.5 per cent). Man-made and regularly maintained drainage ditches were also found in the agricultural plains, and at 22 of the 25 stations (88 per cent) there was evidence of otters.

The habitat at stations in these three categories could also be graded according to the potential for holts or lying-up sites. Thus, grade 3 habitat comprised stations where there was no bankside vegetation and no caves or piles of rock close to water; grade 2 habitat had some scrub or reed offering limited shelter, while in grade 1 habitat the animals could readily find lying-up sites in productive reed beds, dense bankside thickets of bramble Rubus $s p$, caves or rocks. Table 1 shows the percentages of positive stations found in each grade of each category. Within each category, as habitat improved so the number of stations holding otters increased.

\section{Numbers of Signs}

To compare densities of sprainting sites and of numbers of spraints (signs) found at positive stations the data have been standardised to numbers per $200 \mathrm{~m}$. (as in Macdonald and Mason, in press). Stations where footprints only were found have been omitted from the calculations so that signs refer to spraints only - see Figures 2 and 3. Habitat grades 1 and 2 have been combined, as have lowland stations and ditches. The numbers of sprainting sites have been divided into three categories: fewer than 2 sites $/ 200 \mathrm{~m}, 2-4$ sites $/ 200 \mathrm{~m}$ and more than 4 sites $/ 200 \mathrm{~m}$. The numbers of signs have been divided into $1-10$ signs $/ 200 \mathrm{~m}, 11-20$ signs $/ 200 \mathrm{~m}$ and more than $20 / 200 \mathrm{~m}$. It can be seen that there was a greater number of sites/station in good upland habitat than in poor upland habitat, but the difference between good and poor habitat 

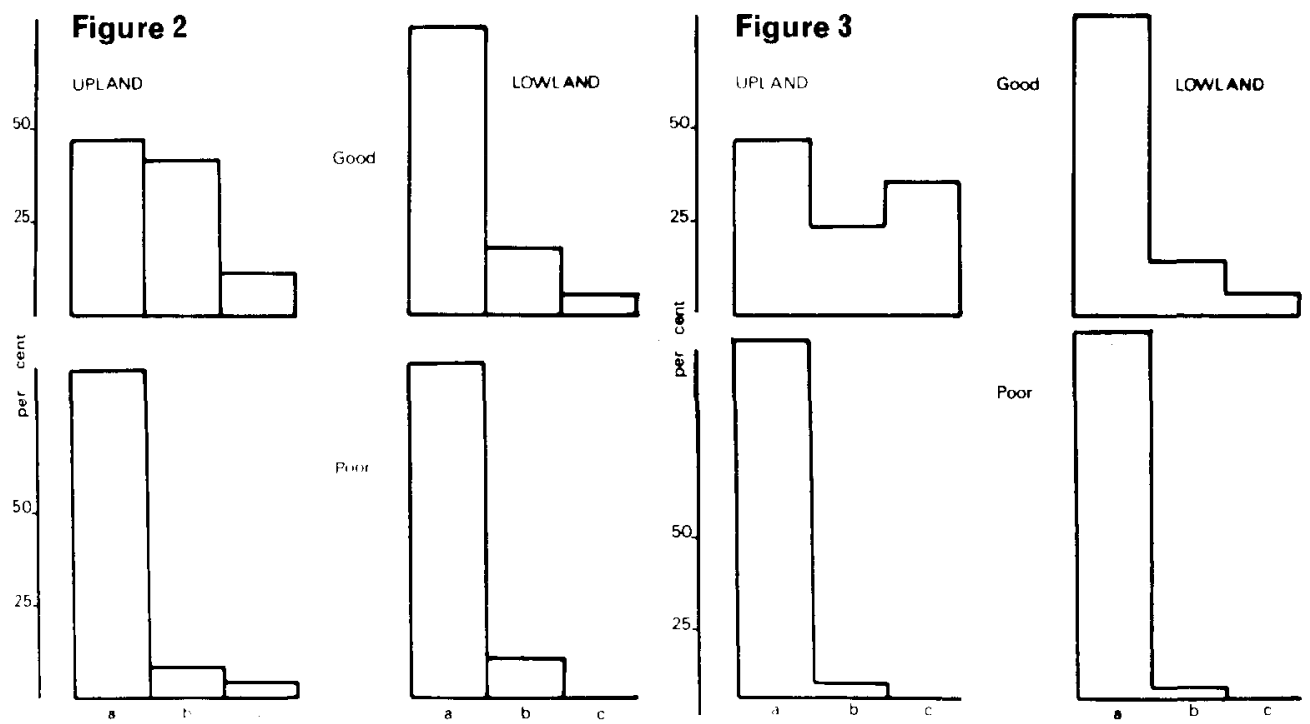

Fig. 2 Percentage of a) under 2, b) 2-4, c) more than 4 sites per $200 \mathrm{~m}$ in good and poor upland and lowland habitat.

Fig. 3 Percentage of a) 1-10, b) 11-20, c) more than 20 signs per $200 \mathrm{~m}$ in good and poor upland and lowland habitat.

in terms of sites in lowland stations is not significant. Similar relationships were found with the number of signs per $200 \mathrm{~m}$. It may be that the heavier marking found in good upland habitat may be related to defence of resources for, while the habitat is good in terms of potential lying-up sites, the food supply in uplands may be limited.

The commonest prey items were fishes; remains were found in 56.2 per cent of 80 spraints collected. Amphibian bones were recorded in 23.7 per cent of the sample and crustaceans in 11.2 per cent, including those of the freshwater crab Potamon fluviatile. The diet was supplemented with mammals (8.7 per cent) e.g. Rattus norvegicus, and birds (7.5 per cent) e.g. moorhen Gallinula chloropus and dabchick Tachybaptus ruficollis, and reptiles to a lesser extent; snake remains occurred in 3.7 per cent of the spraints and terrapin once (1.2 per cent). Several spraints contained insect remains, mostly adult and larval beetles, but these may have derived from larger prey.

\section{Discussion}

Otters were found to be widespread in the area surveyed but distribution was not uniform. Regions which appeared to hold 'good' populations included the western Peloponnese, the plains of the Kiphisos river, the Nestos river delta and the lowlands south of Komotini. By contrast the populations in the eastern Peloponnese and in the lowlands west of Thessaloniki are becoming fragmented.

There have been marked losses in otter habitat through land drainage, and many small rivers are now dry, due to extensive deforestation; in the eastern Peloponnese the low rainfall may exacerbate this problem. Fish species are also harmfully affected by deforestation, and mountain streams throughout the country may not offer sufficient food to maintain otters. Freshwater crabs $P$. fluviatile were seen in such rivers, but fishes may have been restricted to small salmonids, and few amphibians were observed. Lowland rivers offered an 


$\begin{array}{lllll}\begin{array}{l}\text { Table 1 } \\ \text { Grade }\end{array} & \text { Upland (n) } & \text { Lowland (n) } & \text { Ditches (n) } & \text { Overall } \\ 1 & 85.0(2 ;) & 75.9(29) & 100.0(13) & 83.9 \\ 2 & 54.8(42) & 58.6(29) & 77.8(9) & 58.8 \\ 3 & 11.1(18) & 42.3(26) & 66.6(3) & 31.9\end{array}$

The percentage of stations positive for otters in upland, lowland and drainage ditches with habitat graded from 1 (good) to 3 (poor).

abundance of prey species and the diversity is reflected in the results of the spraint analyses.

Most of the plains in mainland Greece are man-made environments, being agricultural and transected by numerous irrigation ditches. Yet otters thrived in several regions despite the intensive maintainance and use of herbicides many empty cannisters of the herbicide MCPA were found. Ditch dredging on rotation means that there are always dense growths of reeds Phragmites and reed-mace Typha somewhere in the ditches; there are few bankside trees but dense and extensive thickets of bramble where otters could certainly find shelter, were frequent beside the ditches. As a result of the intensive cultivation sheep and goats can often only be grazed on field verges and along the ditches, and if the bramble were removed to provide additional pasture for them this could mean a serious loss of habitat for otters. In certain regions, e.g. the plain of the Kiphisos river, caves and rocks offered potential for lying-up sites, but in other regions, such as the Nestos delta, reed and bramble provided the most obvious shelter. All the drainage ditches where there was ample shelter held otters. Indeed, where habitat was good the percentage of positive stations never fell below 75 per cent - see Table 1 . The poorest stations were upland rivers with no bankside cover, where food supplies could also be limiting.

Upland areas in general may hold a poorer density and diversity of prey items. Comparisons between upland and lowland stations where sufficient cover was available revealed a greater density of marking by otters (numbers of sprainting sites and signs) at upland stations - figures 2 and 3. The overall percentages of positive stations do not suggest higher numbers of animals present in uplands and it may be that intensity of marking is, in part, related to defence of food resources.

\section{References}

1. MACDONALD, S.M. \& MASON, C.F. (in press). The otter (Lutra lutra) in central Portugal. Biolngical Conservation.

2. MÜFFLING, S.F. von. 1977. Fischotter in Europa. Loizenkirchen.

3. PANTELOURIS, E.M. 1980. Greece, an introduction. 176pp. Blueacre Books, Glasgow.

4. REUTHER, C. \& FESTETICS, A. (in press). Der fischotter in Europa Verbreitung, Bedrohung, Erhaltung. Proceedings of the first international otter colloquium. Göttingen

5. THORNBACK, J. 1980. Draft list of threatened mammals of the Mediterranean. United Nations Environment Programme. UNEP/IG20/INF 8. Athens.

Dr S.M. Macdonald, The Vincent Wildlife Trust, c/o Department of Zoology \& Comparative Physiology, University of Birmingham, Birmingham B15 2TT.

DrC.F. Mason, Department of Biology, University of Essex, Colchester. 